\title{
Universal CARs, universal T cells, and universal CAR T cells
}

\author{
Juanjuan Zhao, Quande Lin, Yongping Song and Delong Liu* (B)
}

\begin{abstract}
Currently, the two approved T cell products with chimeric antigen receptors (CAR) are from autologous T cells. These CAR $T$ cells approved for clinical use must be generated on a custom-made basis. This case-by-case autologous $T$ cell production platform remains a significant limiting factor for large-scale clinical application due to the costly and lengthy production process. There is also an inherent risk of production failure. The individualized, custom-made autologous CAR T cell production process also posts constriction on the wide application on diverse tumor types. Therefore, universal allogeneic $T$ cells are needed for the preparation of universal CAR T cells that can serve as the "off-the-shelf" ready-to-use therapeutic agents for large-scale clinical applications. Genome-editing technologies including ZFN (zinc finger nuclease), TALEN (transcription activator-like effector nuclease), and CRISPR-Cas9 are being used to generate the universal third-party T cells. In addition, split, universal, and programmable (SUPRA) CARs are being developed to enhance the flexibility and controllability of CAR T cells. The engineered universal T cells and universal CARs are paving the road for a totally new generation of CAR T cells capable of targeting multiple antigens and/ or being delivered to multiple recipients without re-editing of $T$ cells. This may escalate to a new wave of revolution in cancer immunotherapy. This review summarized the latest advances on designs and development of universal CARs, universal T cells, and clinical application of universal CAR T cells.
\end{abstract}

\section{Introduction}

Chimeric antigen receptors (CARs) are engineered receptors that typically contain the antigen-binding region of a monoclonal antibody (mAb), $\mathrm{T}$ cell receptor transmembrane domain, and an intracellular signaling domain of CD3 zeta chain [1-7]. This is the structure of the first generation of CARs (Fig. 1) [8, 9]. Upon binding to a specific antigen, CAR can transmit the signal and activate the $\mathrm{T}$ cells. The $\mathrm{T}$ cells that have been genetically engineered to express CAR can undergo specific immune responses, avoiding the restriction traditionally conferred by the major histocompatibility complex (MHC).

The first generation of CAR T cells was found to have limited proliferative capacity and short survival. Currently, the FDA-approved CAR T cell products belong to the second generation of CAR T cells $[9,10]$. The second generation of CARs contains a single co-stimulatory domain

\footnotetext{
* Correspondence: delong_liu@nymc.edu

The Affiliated Cancer Hospital of Zhengzhou University and Henan Cancer Hospital, 127 Dongming Road, Zhengzhou 450008, China
}

(CD28 or 4-1BB), whereas the third generation of CARs may have two or more co-stimulatory domains (CD27, CD28, 4-1BB, or OX40) [9, 11-18] (Fig. 1). Additional molecular elements have been inserted into the CAR constructs to express functional transgenic proteins $[10,19-$ 22]. This defines the fourth generation CARs which may contain a controllable on-off switch, a suicide gene, or a molecule to enhance $\mathrm{T}$ cell function, enrichment, and minimize senescence $[21,23]$. Over the last few years, significant modifications have been made to further improve the CAR T designs. Bispecific CARs can simultaneously target two antigens and/or epitopes to limit immune escape [24]. Universal CARs are being developed to increase flexibility and controllability as well as scalability. To increase efficacy and potency, functional elements such as interleukin genes are inserted into the fourth generation CAR constructs. To increase safety and controllability, on-off-switches or suicide genes are built into the new CARs.

The enormous potential of the CAR T cells has been confirmed in clinical studies of adult and pediatric cancer treatment [7, 13, 25-29]. Two CD19-engineered 


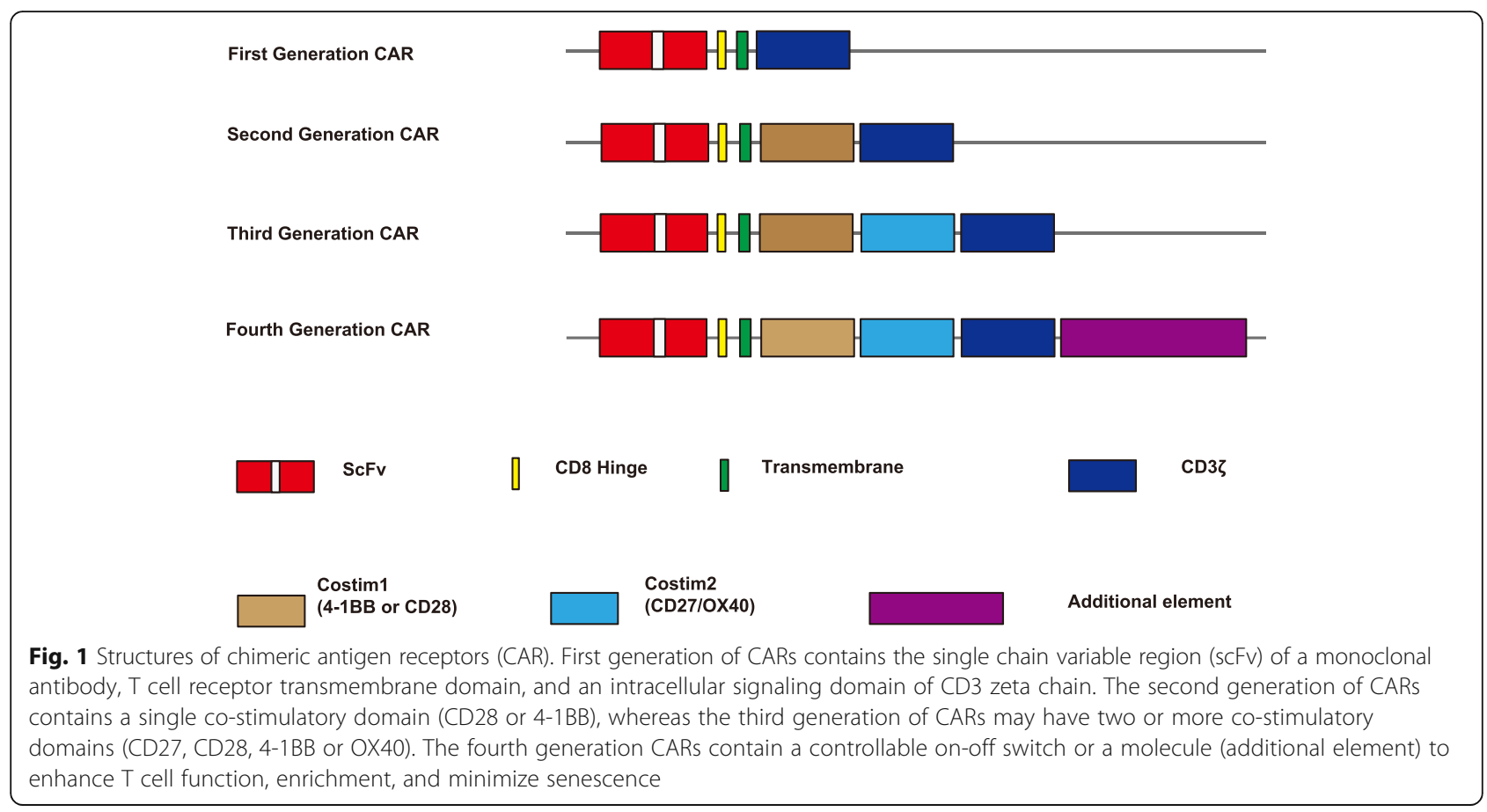

CAR $\mathrm{T}$ cell products have been approved for clinical treatment of B lymphoid malignancies [27, 30-38]. These CAR T cells are autologous lymphocytes from patients. However, this patient-specific autologous $\mathrm{T}$ cell paradigm is a significant limiting factor for large-scale deployment of the CAR technology as the CAR T cell product is individualized and therefore varies from patient to patient. It is hence not a ready-to-use preparation of conventional therapeutic agents. The individualized manufacturing process is costly and time-consuming. In addition, generation of sufficient number of custom-made autologous $\mathrm{T}$ cells may not be feasible or successful in all cases, particularly for infants or highly treated patients who are profoundly lymphopenic owing to multiple previous chemotherapies and/or stem cell transplantation. Furthermore, each CAR has a fixed antigen specificity such that each CAR T preparation can only target one epitope of a specific antigen, limiting the efficacy due to heterogeneous tumor antigen expression and tumor antigen escape. The universal "off-the-shelf" CAR T cells that can be simultaneously or sequentially administered to multiple patients can effectively solve the above problems. This review summarized the recent advances in the designs and applications of universal CAR T cells.

\section{Universal CARs: design principles and early studies}

The current CAR $\mathrm{T}$ cell therapy is limited by antigen specificity and scalability since each CAR $\mathrm{T}$ cell system targets only one antigen or two antigens [24]. To increase flexibility and expand antigen recognition, new CARs are being designed and tested as universal CARs.
These CARs use a "third-party" intermediate system that splits the antigen-targeting domain and the T cell signaling unit [39-41]. This "third-party" "lock-key" split CAR system confers CAR $\mathrm{T}$ cells with near-infinite antigen specificity.

\section{BBIR CAR: biotin-binding immune receptor}

To use the biotin-avidin "lock-key" mechanism for CAR engineering, avidin was used as the extracellular domain linked to an intracellular T cell signaling domain (Fig. 2) [39]. This creates a system of biotin-binding immune receptors (BBIR). The BBIR containing dimeric avidin (dcAv BBIR) was able to efficiently recognize and bind a variety of biotinylated antigen-specific molecules (scFV, mAbs, or tumor-specific ligands), whereas the BBIR containing monomeric avidin (mcAv BBIR) did not result in a specific immune response, probably due to poor affinity between biotin and monomeric avidin.

dcAv BBIRs were able to react specifically to targeted antigens in the presence of extremely low concentrations of biotinylated molecules (such as Bio-EpCAM Ab at $0.1 \mathrm{ng} / \mathrm{mL}$ ). The same batch of genetically modified $\mathrm{T}$ cells was shown to recognize multiple tumor-associated antigens (TAAs), FR $\alpha$, EpCAM, and mesothelin, respectively, after the addition of matched biotinylated antibodies (Abs). The BBIRs can also sequentially recognize diverse TAAs via stepwise addition of corresponding biotinylated Abs [39]. These findings confirmed the versatility of the BBIR platform.

The BBIR T cells showed a strong inhibition of tumor growth in the xenograft mouse model of human ovarian 


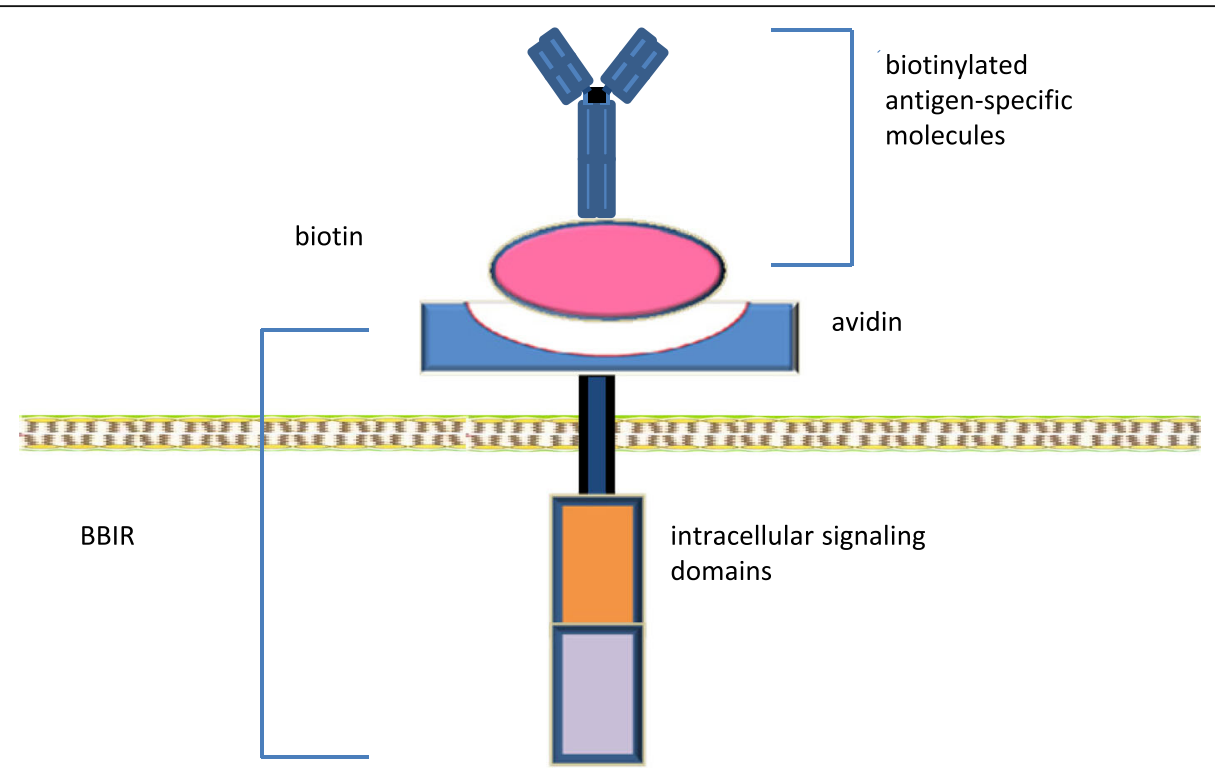

Fig. 2 The structure of BBIR CAR. In the BBIR CAR, avidin serves as the extracellular ligand binding domain and is linked to the transmembrane and intracellular signaling domains. The biotinylated antigen-specific molecules can be full-length antibodies, scFvs, or other tumor-specific ligands. Through the binding of biotin to avidin, any extracellular signal linked to the biotin can activate the $T$ cells. Therefore, the BBIR CAR remains constant and can serve as a universal CAR. (adapted from Urbanska, K, et al.; Cancer Res. 2012; 72(7); 1844-1852)

cancer following the addition of biotinylated corresponding antibody [39]. This BBIR platform of universal CAR system has the potential to significantly extend conventional CAR approaches and generate $\mathrm{T}$ cells of unlimited antigen specificity.

Using the biotin-avidin system, a similar universal CAR was constructed [40]. The anti-tag CAR T cells were recently tested to target $\mathrm{CD} 19^{+}$and $\mathrm{CD} 20^{+}$cells. One concern of this system is the immunogenicity of avidin. Further testing of the biotin-avidin anti-tag CAR $\mathrm{T}$ cells in an animal model and clinical trial will be needed.

\section{SUPRA CARs}

To enhance the flexibility and controllability of CARs, a split, universal, and programmable (SUPRA) CAR system was invented [42]. SUPRA CAR is a two-component receptor system consisting of a universal receptor with leucine zipper adaptor (zipCAR) on $\mathrm{T}$ cells and a separate $\mathrm{scFv}$ with leucine zipper adaptor (zipFv) molecule targeting specific antigens (Fig. 3). This split "lock-key" structure of SUPRA CAR with leucine zipper adaptors indeed has several clinically relevant advantages over a rigid CAR system:

1. Antigen targets of one set of zipCAR T cells can be switched, expanded and combined without further modification of the CAR T cells. Targets of the split scFv adaptor can be switched easily without affecting the effector $\mathrm{T}$ cells since the zipCAR $\mathrm{T}$ cells remain unchanged. This therefore expands the repertoire of targetable antigens for a set zipCAR $\mathrm{T}$ system. This theater-array combination of different targets of effector $\mathrm{T}$ cells can effectively counter tumor escape, and reduce relapse.

2. The activities and toxicities of SUPRA CAR T cells can be controlled and fine-tuned. This can be achieved by adjusting the binding strength through variable leucine zipper configurations. This leads to the defined potency of $\mathrm{T}$ cell signaling and thus the degree of $\mathrm{T}$ cell activation. By the same mechanism, a zipFv with no specific antigen target can be used to competitively tune down zipCAR $\mathrm{T}$ cell activation to minimize or terminate the toxicities.

3. Signaling domains and effector cell types can be changed and combined. Orthogonal zipCARs can be connected to different intracellular signal domains in the same cell or assembled to differently engineered cell types with defined ratios, thus enabling precise controllability of different signal domains or cells types (such as NK cells), potentially achieving the precise, tailored fine-tuning of effector cell responses [42].

In the mouse xenograft models of breast cancer and leukemia, the SUPRA CAR system demonstrated a robust anti-tumor effect comparable to that of conventional CAR $\mathrm{T}$ cells [42]. With the versatility and controllability, the 


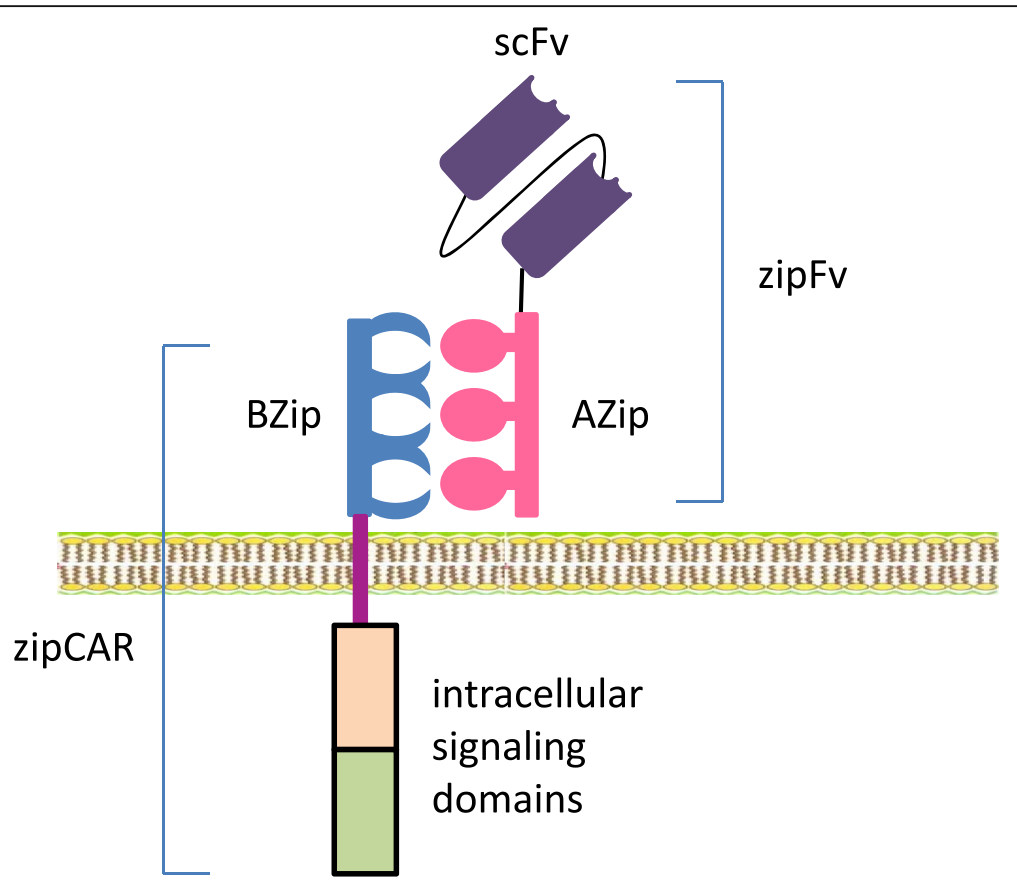

Fig. 3 The structure of SUPRA CAR. A SUPRA CAR system consists of a zipCAR and a zipFv. A zipFv has a scFv linked to a leucine zipper (AZip). A zipCAR has a cognate leucine zipper (BZip) that can bind to the AZip. Through the binding between A- and B-leucine zippers, any extracellular signal linked to the AZip can activate the T cells. Therefore, the SUPRA CAR remains constant and can serve as a universal CAR. The affinity between the A- and B-leucine zippers can be adjusted so that the signaling strength and activity can be dialed up or down as desired. When AZip is linked to a null antigen, the signaling is quenched, and T cells become inactive. (adapted from Choi, JH, et al., Cell 2018; 173: 1-13)

SUPRA CAR system represents a superior universal CAR design.

\section{Universal T cells: design principles and preclinical studies Generation of universal $T$ cells}

Currently, the two approved CAR $\mathrm{T}$ cell products are from autologous $\mathrm{T}$ cells. These CAR T cells approved for clinical use must be generated on a custom-made basis.

This patient-specific autologous $\mathrm{T}$ cell production platform calls for highly skilled and dedicated facility as well as substantial investment in infrastructure. In addition, it is very time-consuming and precludes immediate administration when the most critically ill patients need the therapy, since the generation of a therapeutic product requires a lengthy and individualized manufacturing process. There is also an inherent risk of production failure as there is no guarantee that the generation of sufficient number of custom-made autologous $\mathrm{T}$ cells can always be feasible for patients who are critically ill and profoundly lymphopenic owing to previous chemotherapy, radiation therapy, and/or stem cell transplantation. This costly and time-consuming process also posts constriction on the wide application on diverse tumor types. Therefore, universal $\mathrm{T}$ cells are needed for the preparation of universal CAR T cells.

The main design principle for generating universal CAR $\mathrm{T}$ cells is to generate tumor antigen-specific $\mathrm{T}$ cells from allogeneic healthy donors. The common basis of this method is to effectively abolish graft-versus-host disease (GVHD) by genetically disrupting the TCR gene and/or HLA class I loci of the allogeneic T cells. By targeting genomic sequences in the constant regions of the endogenous $\alpha$ or $\beta$ subunits of the TCR or disrupting HLA-A locus of MHC gene complex, the expression of TCR or the HLA class I antigens is abrogated, and the resulting $\mathrm{T}$ cells are not capable of recognizing allogeneic antigens, thus leading to the elimination of GVHD. These allogeneic $\mathrm{T}$ cells from healthy donors are universal $\mathrm{T}$ cells and can be used to generate universal CAR $\mathrm{T}$ cells for specific antigens of interest. Zinc finger nuclease $(Z F N)[43,44]$, transcription activator-like effector nuclease (TALEN)[45], and CRISPR/Cas9 system [23, 46, 47] are the most commonly used gene-editing methodologies for generating TCR-deficient and HLA class I-deficient T cells.

\section{ZFN: zinc finger nuclease}

ZFN is a designed specific DNA endonuclease that can result in a double-strand break of a user-defined gene target. Repairing the cleaved sites through non-homologous end joining or homology-directed DNA repair pathway can cause deletion or insertion of nucleotides, resulting in permanent loss of the target gene expression [48-51]. Using this genome-editing technology, the expression of TCR $\alpha$ 
constant (TRAC) or the TRBC chains in T cells were disrupted, leading to loss of TCR function [43, 44]. These modified $\mathrm{T}$ cells were shown to be anergic and not able to respond to TCR-specific stimulation. These CAR T cells were also shown to have no imbalance of $\mathrm{T}$ cell subsets $\left(\mathrm{CD}^{+}\right.$or $\left.\mathrm{CD}^{+}\right)$[43]. Using the same approach, the HLA-A gene was disrupted. This population of ZFN-edited $T$ cells was readily enriched through negative selection for HLA-positive cells [44]. These TCR-deficient or HLA-A-deficient T cells did not cause GVHD in animal models. The TCR ${ }^{\text {neg }} \mathrm{T}$ cells have been used for generation of universal CAR T cells which may offer an "off-the-shelf" immunopharmaceuticals [43, 44] (Fig. 4). Clearly, further clinical testing is needed to confirm the clinical potential.

\section{TALEN: transcription activator-like effector nuclease}

Transcription activator-like effector (TALE) was initially discovered in plant [52, 53], and TALE nuclease (TALEN) is another designed site-specific endonuclease that has been used for genome-editing in a variety of species [54-57]. By application of TALEN gene-editing technology, the TCR $\alpha$ constant (TRAC) gene was disrupted, eliminating the potential for $\mathrm{T}$ cells to react to allogeneic antigens and mediate GVHD [45]. To abolish the possibility of any remaining alloreactive $\mathrm{T}$ cells and facilitate the engraftment of third-party CAR $\mathrm{T}$ cells, CD52 gene in the CAR T cells was simultaneously disrupted by TALEN (Fig. 5) [45]. This established a process for the large-scale manufacturing of healthy readily available "off-the-shelf" $\mathrm{T}$ cells deficient in expression of both $\mathrm{T}$ cell receptor and CD52. Alemtuzumab, a monoclonal antibody against CD52, has been used to destroy and eliminate remaining $\mathrm{CD} 52^{+}$ wild-type alloreactive $\mathrm{T}$ cells, thereby enriching the desired TCR-less CAR $\mathrm{T}$ cells. These TALEN-edited healthy allogeneic $\mathrm{T}$ cells do not incite GVHD and are resistant to destruction by alemtuzumab. These $\mathrm{T}$ cells were used for the generation of universal CAR T cells.
As a proof of concept for the general application of this platform, TCR/CD52-deficient CD19 CAR T cells (dKO-CART19) were generated [45]. The dKO-CART19 universal $\mathrm{T}$ cells were shown to be deficient of alloreactivity, and the engraftment was facilitated by alemtuzumab. These universal $\mathrm{T}$ cells demonstrated antitumor activity indistinguishable from standard CD19 CAR T cells [45]. This manufacturing platform therefore has the potential for large-scale manufacturing of universal CAR $\mathrm{T}$ cells that are similar to a traditional drug ready for administration as an "off-the-shelf" agent.

\section{CRISPR/Cas9: clustered regularly interspaced short palindromic repeat (CRISPR)/ CRISPR- associated protein 9 (Cas9)}

Both ZFN- and TALEN-based methodologies require designing specific pairs of nucleases for each new gene target. This has a great limit on the wide application of the technology. The CRISPR-Cas9 system was discovered in 2012 [58]. CRISPR-Cas9 system has been widely used for genome editing since it can be efficiently programmed to cleave DNA and induce indels at sites of interest [59-67]. Highly efficient double knockout of endogenous TCR and HLA class I (b2-microglobulin, B2M) was achieved via a one-shot CRISPR protocol to generate allogeneic universal CAR T cells (Fig. 6) [23, 68]. With this technology, multiplex genome editing was possible. Additional genes, such as PD1 and CD52 were edited, and universal CAR T cells were generated and proven to be functional as designed.

Through a CRISPR-CAR coupled lentiviral vector, CAR19 was introduced simultaneously, leading to the production of TCR-depleted CAR19 T cells [46]. The universal CAR19 $\mathrm{T}$ cells were highly homogeneous and had potent antileukemia activity in a human: murine chimeric tumor model. This approach was shown to be scalable through an automated separation process and may serve as a good platform for the generation of "universal" human T cells on a clinical scale.

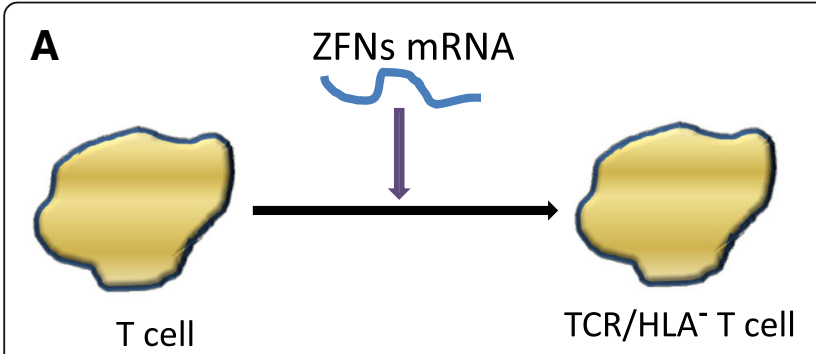

B

TRAC: $14 \mathrm{q} 11.2$

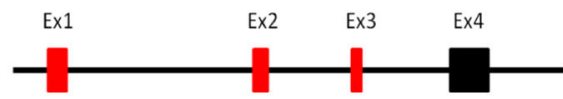

TRAC-ZFN-2 AGTGCTGTGGCCTGGAGCAACAAATCTGACT T TGCATGTGCAAA ||| || ||| ||| |||||||||| |||||||||| ||| ||||||||||| | | TCACGACACCGGACCTCGTTG TTTAGACTGAAACGTACACGTT T TRAC-ZFN-1

Fig. 4 Production of universal TCR $/ H L A^{-} T$ cells using ZFN (zinc finger nuclease). a The T cells were obtained from healthy adult donors. ZFN mRNA pairs were delivered to the T cells by electroporation. ZFN pairs designed to target TCR aor $\beta$ constant regions and HLA-A lead to DNA double-strand breaks at the given sites and cause deletion or insertion of nucleotides, resulting in permanent loss of gene expression. These TCR ${ }^{-} / H_{L} A^{-} T$ cells made from allogeneic healthy donors can be used as universal T cells for preparation of "off-the-shelf" CAR T cells. b Structure of the ZFN pair. One ZFN pair was designed to bind exon 1 of the TCRa constant region (TRAC), and the underlined nucleotide sequences represent the targeted binding sequences. The red blocks represent coding regions and the black block represents a noncoding region (adapted from Torikai H, et al. Blood 2012; 119(24):5697-5705) 


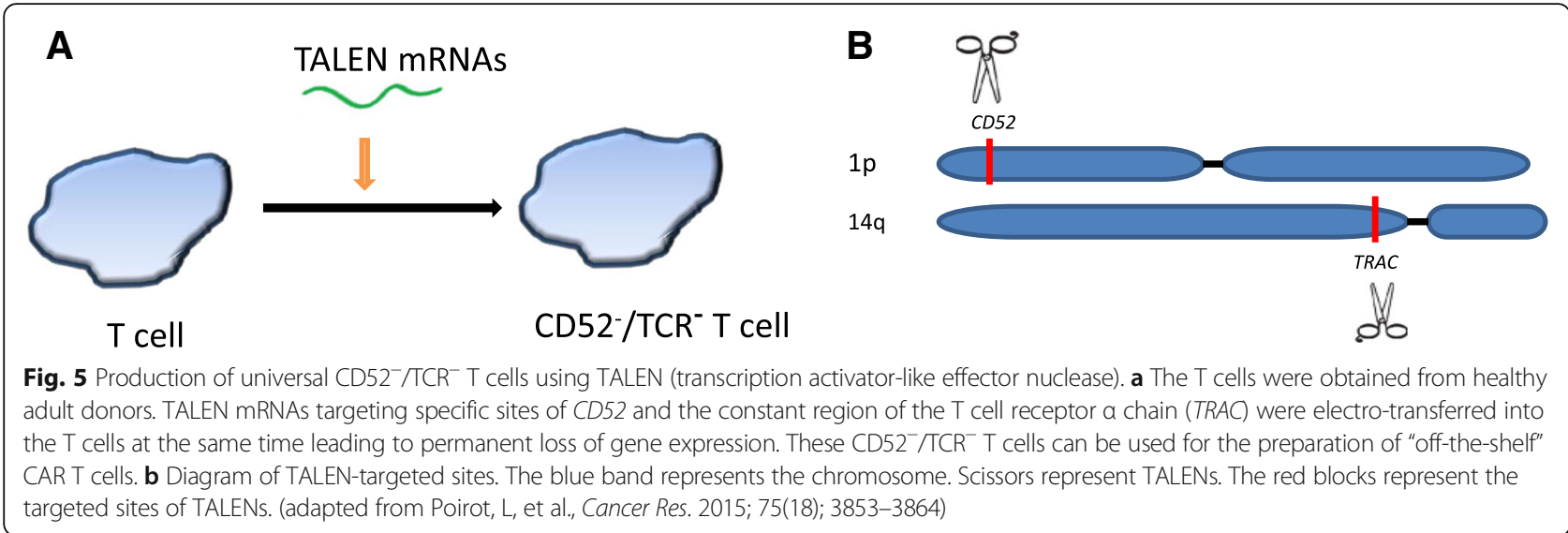

CRISPR-Cas9 was used successfully for multiplex gene editing in CAR T cells $[69,70]$. Two (TRAC and B2M) or three genes (TRAC, B2M, and PD-1) were disrupted in the CAR T cells [69]. TRAC and B2M were disrupted with high efficiency, yet only $64.7 \%$ of the clones of the PD-1 PCR products were mutants. This implies that $\mathrm{T}$ cells with PD-1 mutations were not optimally enriched by the negative selection-based enrichment method as the PD-1 expression was downregulated during $\mathrm{T}$ cell expansion. The TCR-deficient CAR T cells were shown to have cytotoxic anti-tumor functions in vitro and in vivo. The safety and efficacy of these $T C R^{\text {neg }}$ CAR T cells must be characterized in clinical trials.

\section{FT819, iPSC CAR iT cells}

A universal CAR 19 T cell line, FT819, was generated from an induced pluripotent stem cell (iPSC) line [71]. An iPSC cell line was established from healthy peripheral blood $\mathrm{T}$ cells which also contain a CD19-targeted CAR and bi-allelic TRAC locus disruption. TCR-less CAR19 T cells were successfully generated from the iPSC master line. The CAR19 iT cells were fully functional in vitro. A clinical trial in human is required to fully assess the safety and efficacy of this first-of-the-kind off-the-shelf CAR iT cell product.

\section{Clinical studies of universal CAR T cells}

TALEN gene-edited TCR-deficient CAR T cells are being studied in humans through clinical trials. Two infants with highly relapsed refractory CD19 ${ }^{+}$B-ALL were treated with the allogeneic universal CAR T cells [72]. The two children achieved cytogenetic and molecular remission after the universal CAR T therapy and went on to receive allogeneic stem cell transplantation successfully.

Clinical trials of CRISPR/Cas9 gene-edited universal allogeneic CAR T cells have been initiated (NCT03166878, NCT03229876). Both were CD19-targeted CAR T cells. Details and outcomes are not yet available.

\section{Future perspectives}

By disrupting TCR expression and/or MHC on allogeneic third-party $\mathrm{T}$ cells, universal $\mathrm{T}$ cells have been generated. These $\mathrm{T}$ cells do not cause GVHD and can be widely used to generate "off-the-shelf" CAR T cells. However, there are still key issues that urgently need to

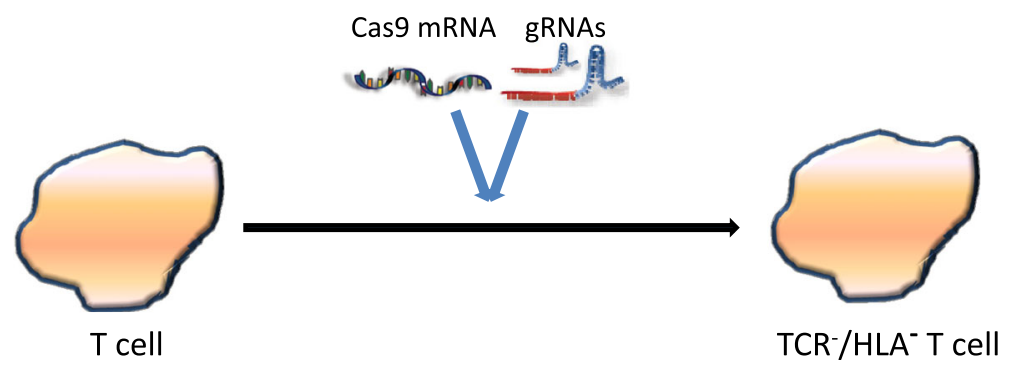

Fig. 6 Production of universal TCR $/ H L A^{-}$T cells using the CRISPR/Cas9 system (clustered regularly interspaced short palindromic repeat /CRISPRassociated protein 9). The T cells were obtained from healthy adult donors. Cas9 mRNA and gRNAs targeting the constant region of the T cell receptor aor $\beta$ chain (TRAC or TRBC) and $B_{2} M$ were transferred to T cells by electroporation. The Cas 9 endonuclease is capable of cleaving the TRAC, TRBC, and $B_{2} M$ under the guidance of corresponding gRNAs and inducing indels at pre-validated sites. These universal TCR $/ H L A^{-} T$ cells with reduced alloreactivity can be used for the preparation of "off-the-shelf" CAR T cells. (adapted from Ren, J, et al. Clin Cancer Res. 2016; 23(9); 2255-2266) 
be resolved before the practical application of universal CAR T cells. For example, there exists the risk of GVHD caused by even less than $1 \%$ of $\mathrm{TCR}^{+}$cells remaining in $\mathrm{TCR}^{-}$cell preparation. The potential off-target effects and abnormal genotypes that arise during gene editing still require attention and further researches [73, 74]. Universal CAR T cell therapy is still at its infancy. Many issues require further explorations, particularly in the following areas:

1. Clinical trials in more patients to ascertain the efficacy and toxicity

2. Long-term follow-up to monitor the rate of acute and chronic GVHD, rejection, T cell exhaustion/ senescence, and target antigen escape

3. Combination of allogeneic CAR $\mathrm{T}$ cells either sequentially and/or simultaneously to target multiple antigens in one type of cancer

4. Establishment and unification of clinical, industrial, and regulatory standards for universal CAR $\mathrm{T}$ cell therapy, such as the criteria for efficacies and toxicities, and manufacturing standards throughout the world

5. Revision and adoption of new reimbursement models for universal CAR T cell therapy since this type of therapy has high upfront cost and may induce long-term remission/cure or turn cancer into a chronic illness through repeated or maintenance infusions of CAR T cells

6. Application of CAR T therapy for other illnesses like autoimmune diseases and AIDS

\section{Conclusion}

Genome-editing methodologies including ZFN, TALEN, and CRSIPR-Cas9 make it possible to generate universal third-party T cells. Split, universal, and programmable (SUPRA) CARs offer the flexibility and controllability of CAR T cells. A new generation of universal CAR T cells is in clinical trials and offers novel armamentarium for cancer immunotherapy.

\section{Abbreviations}

CAR: Chimeric antigen receptor; CRISPR/Cas9: Clustered regularly interspaced short palindromic repeat (CRISPR)-CRISPR- associated 9 (Cas9); TALEN: Transcription activator-like effector nuclease; ZFN: Zinc finger nuclease

\section{Acknowledgements}

$\mathrm{DL}$ is a professor of medicine in the Department of Medicine, New York Medical College and Westchester Medical Center, Valhalla, NY, USA.

\section{Funding}

The study is partly supported by the Affiliated Caner Hospital of Zhengzhou University, Zhengzhou, China.

\section{Availability of data and materials}

The material supporting the conclusion of this review has been included within the article.

\section{Authors' contributions}

$\mathrm{DL}$ and $\mathrm{JZ}$ designed the study and drafted the manuscript. QL prepared Fig. 1. All authors participated in the revision of the manuscript. All authors read and approved the final manuscript.

Ethics approval and consent to participate

This is not applicable for this review.

Consent for publication

This is not applicable for this review.

\section{Competing interests}

The authors declare that they have no competing interests.

\section{Publisher's Note}

Springer Nature remains neutral with regard to jurisdictional claims in published maps and institutional affiliations.

Received: 26 September 2018 Accepted: 15 November 2018

Published online: 27 November 2018

\section{References}

1. Porter DL, Kalos M, Zheng Z, Levine B, June C. Chimeric antigen receptor therapy for B-cell malignancies. J Cancer. 2011;2:331-2.

2. Riddell $\mathrm{SR}$, Jensen $\mathrm{MC}$, June $\mathrm{CH}$. Chimeric antigen receptor--modified $\mathrm{T}$ cells: clinical translation in stem cell transplantation and beyond. Biol Blood Marrow Transplant. 2013;19(1 Suppl):S2-5.

3. Kochenderfer JN, Feldman SA, Zhao Y, Xu H, Black MA, Morgan RA, Wilson WH, Rosenberg SA. Construction and preclinical evaluation of an anti-CD19 chimeric antigen receptor. J Immunother. 2009;32(7):689-702.

4. Sadelain M. T-cell engineering for cancer immunotherapy. Cancer J. 2009; 15(6):451-5

5. Sadelain M, Riviere I, Brentjens R. Targeting tumours with genetically enhanced T lymphocytes. Nat Rev Cancer. 2003;3(1):35-45

6. Cooper $\amalg$, Kalos M, DiGiusto D, Brown C, Forman SJ, Raubitschek A, Jensen MC. T-cell genetic modification for re-directed tumor recognition. Cancer Chemother Biol Response Modif. 2005;22:293-324.

7. Pule MA, Savoldo B, Myers GD, Rossig C, Russell HV, Dotti G, Huls MH, Liu E, Gee AP, Mei Z, Yvon E, Weiss HL, Liu H, Rooney CM, Heslop HE, Brenner MK Virus-specific T cells engineered to coexpress tumor-specific receptors: persistence and antitumor activity in individuals with neuroblastoma. Nat Med. 2008;14(11):1264-70.

8. June CH, O'Connor RS, Kawalekar OU, Ghassemi S, Milone MC. CAR T cell immunotherapy for human cancer. Science. 2018;359(6382):1361-5.

9. June $\mathrm{CH}$, Sadelain M. Chimeric antigen receptor therapy. N Engl J Med. 2018;379(1):64-73.

10. Liu B, Song Y, Liu D. Clinical trials of CAR-T cells in China. J Hematol Oncol. 2017;10(1):166.

11. Brentjens RJ. Are chimeric antigen receptor T cells ready for prime time? Clin Adv Hematol Oncol. 2016;14(1):17-9.

12. Brentjens RJ, Curran KJ. Novel cellular therapies for leukemia: CAR-modified T cells targeted to the CD19 antigen. Hematology Am Soc Hematol Educ Program. 2012;2012:143-51.

13. Brentjens RJ, Davila ML, Riviere I, Park J, Wang X, Cowell LG, Bartido S, Stefanski J, Taylor C, Olszewska M, Borquez-Ojeda O, Qu J, Wasielewska T, He Q, Bernal Y, Rijo IV, Hedvat C, Kobos R, Curran K, Steinherz P, Jurcic J, Rosenblat T, Maslak P, Frattini M, Sadelain M. CD19-targeted T cells rapidly induce molecular remissions in adults with chemotherapy-refractory acute lymphoblastic leukemia. Sci Transl Med. 2013;5(177):177ra138.

14. Brentjens RJ, Riviere I, Park JH, Davila ML, Wang X, Stefanski J, Taylor C, Yeh R, Bartido S, Borquez-Ojeda O, Olszewska M, Bernal Y, Pegram H, Przybylowski M, Hollyman D, Usachenko Y, Pirraglia D, Hosey J, Santos E, Halton E, Maslak P, Scheinberg D, Jurcic J, Heaney M, Heller G, Frattini M, Sadelain M. Safety and persistence of adoptively transferred autologous CD19-targeted T cells in patients with relapsed or chemotherapy refractory B-cell leukemias. Blood. 2011;118(18):4817-28.

15. Jackson HJ, Rafiq S, Brentjens RJ. Driving CAR T-cells forward. Nat Rev Clin Oncol. 2016;13(6):370-83.

16. Wang Z, Wu Z, Liu Y, Han W. New development in CAR-T cell therapy. J Hematol Oncol. 2017;10(1):53. 
17. Yu S, Li A, Liu Q, Li T, Yuan X, Han X, Wu K. Chimeric antigen receptor T cells: a novel therapy for solid tumors. J Hematol Oncol. 2017;10(1):78

18. Zhang C, Liu J, Zhong JF, Zhang X. Engineering CAR-T cells. Biomarker Res. 2017;5(1):22.

19. Pegram HJ, Lee JC, Hayman EG, Imperato GH, Tedder TF, Sadelain M, Brentjens RJ. Tumor-targeted T cells modified to secrete IL-12 eradicate systemic tumors without need for prior conditioning. Blood. 2012;119(18): 4133-41.

20. Chmielewski M, Kopecky C, Hombach AA, Abken H. IL-12 release by engineered $T$ cells expressing chimeric antigen receptors can effectively muster an antigen-independent macrophage response on tumor cells that have shut down tumor antigen expression. Cancer Res. 2011;71(17): 5697-706.

21. Pegram HJ, Purdon TJ, van Leeuwen DG, Curran KJ, Giralt SA, Barker JN, Brentjens RJ. IL-12-secreting CD19-targeted cord blood-derived T cells for the immunotherapy of B-cell acute lymphoblastic leukemia. Leukemia. 2015; 29(2):415-22.

22. Zhang $\mathrm{E}, \mathrm{Xu} \mathrm{H}$. A new insight in chimeric antigen receptor-engineered $\mathrm{T}$ cells for cancer immunotherapy. J Hematol Oncol. 2017;10(1):1.

23. Ren J, Liu X, Fang C, Jiang S, June CH, Zhao Y. Multiplex genome editing to generate universal CAR T cells resistant to PD1 inhibition. Clin Cancer Res. 2017;23(9):2255-66.

24. Ruella M, Barrett DM, Kenderian SS, Shestova O, Hofmann TJ, Perazzelli J, Klichinsky M, Aikawa V, Nazimuddin F, Kozlowski M, Scholler J, Lacey SF, Melenhorst JJ, Morrissette JJ, Christian DA, Hunter CA, Kalos M, Porter DL, June CH, Grupp SA, Gill S. Dual CD19 and CD123 targeting prevents antigen-loss relapses after CD19-directed immunotherapies. J Clin Invest. 2016;126(10):3814-26.

25. Grupp SA, Kalos M, Barrett D, Aplenc R, Porter DL, Rheingold SR, Teachey DT, Chew A, Hauck B, Wright JF, Milone MC, Levine BL, June CH. Chimeric antigen receptor-modified $T$ cells for acute lymphoid leukemia. N Engl J Med. 2013;368(16):1509-18

26. Porter $\mathrm{DL}$, Levine BL, Kalos M, Bagg A, June $\mathrm{CH}$. Chimeric antigen receptormodified T cells in chronic lymphoid leukemia. N Engl J Med. 2011;365(8):725-33.

27. Maude SL, Frey N, Shaw PA, Aplenc R, Barrett DM, Bunin NJ, Chew A, Gonzalez VE, Zheng Z, Lacey SF, Mahnke YD, Melenhorst JJ, Rheingold SR, Shen A, Teachey DT, Levine BL, June CH, Porter DL, Grupp SA. Chimeric antigen receptor $T$ cells for sustained remissions in leukemia. N Engl J Med. 2014;371(16):1507-17.

28. Lee DW, Kochenderfer JN, Stetler-Stevenson M, Cui YK, Delbrook C, Feldman SA, Fry TJ, Orentas R, Sabatino M, Shah NN, Steinberg SM, Stroncek D, Tschernia N, Yuan C, Zhang H, Zhang L, Rosenberg SA, Wayne AS, Mackall CL. T cells expressing CD19 chimeric antigen receptors for acute lymphoblastic leukaemia in children and young adults: a phase 1 doseescalation trial. Lancet. 2015:385(9967):517-28.

29. Mikkilineni $\mathrm{L}$, Kochenderfer JN. Chimeric antigen receptor T-cell therapies for multiple myeloma. Blood. 2017;130(24):2594-602.

30. Park JH, Brentjens RJ. Adoptive immunotherapy for B-cell malignancies with autologous chimeric antigen receptor modified tumor targeted T cells. Discov Med. 2010;9(47):277-88.

31. Park JH, Brentjens RJ. Are all chimeric antigen receptors created equal? J Clin Oncol. 2015;33(6):651-3.

32. Park JH, Geyer MB, Brentjens RJ. CD19-targeted CAR T-cell therapeutics for hematologic malignancies: interpreting clinical outcomes to date. Blood. 2016;127(26):3312-20.

33. Park JH, Rivière I, Gonen M, Wang X, Sénéchal B, Curran KJ, Sauter C, Wang Y, Santomasso B, Mead E, Roshal M, Maslak P, Davila M, Brentjens RJ, Sadelain M. Long-term follow-up of CD19 CAR therapy in acute lymphoblastic leukemia. N Engl J Med. 2018;378:449-59.

34. Park JH, Riviere I, Wang X, Senechal B, Wang Y, Mead E, Santomasso B, Halton E, Diamonte C, Bernal Y, Li D, Sadelain M, Brentjens RJ. Durable long term survival of adult patients with relapsed B-ALL after CD19 CAR (19-28z) T-cell therapy. J Clin Oncol. 2017;35(15_suppl):7008.

35. Zhang L-N, Song Y, Liu D. CD19 CAR-T cell therapy for relapsed/refractory acute lymphoblastic leukemia: factors affecting toxicities and long-term efficacies. J Hematol Oncol. 2018;11(1):41.

36. Wei G, Ding L, Wang J, Hu Y, Huang H. Advances of CD19-directed chimeric antigen receptor-modified $T$ cells in refractory/relapsed acute lymphoblastic leukemia. Experiment Hematol Oncol. 2017;6(1):10.

37. Xiao L, Huang $H$, Huang $X$, Ke X, Hu Y, Li J, Zhang Q, Hu Y, Jiang Q, Hu J, Jing $H$, Zhang $X$, Wu Z. Efficacy of anti-CD19 chimeric antigen receptor modified T(CAR-T) cell therapy in Chinese patients with relapsed/refractory acute lymphocytic leukemia in a multicenter trial. J Clin Oncol. 2017;35(15_ suppl):7028

38. Maude SL, Laetsch TW, Buechner J, Rives S, Boyer M, Bittencourt $H$, Bader $\mathrm{P}$, Verneris MR, Stefanski HE, Myers GD, Qayed M, De Moerloose B, Hiramatsu H, Schlis K, Davis KL, Martin PL, Nemecek ER, Yanik GA, Peters C, Baruchel A, Boissel N, Mechinaud F, Balduzzi A, Krueger J, June CH, Levine BL, Wood P, Taran T, Leung M, Mueller KT, et al. Tisagenlecleucel in children and young adults with B-cell lymphoblastic leukemia. N Engl J Med. 2018;378(5):439-48,

39. Urbanska K, Lanitis E, Poussin M, Lynn RC, Gavin BP, Kelderman S, Yu J, Scholler N, Powell DJ Jr. A universal strategy for adoptive immunotherapy of cancer through use of a novel T-cell antigen receptor. Cancer Res. 2012; 72(7):1844-52.

40. Lohmueller JJ, Ham JD, Kvorjak M, Finn OJ. mSA2 affinity-enhanced biotinbinding CAR T cells for universal tumor targeting. Oncoimmunology. 2017; 7(1):e1368604

41. Ma JS, Kim JY, Kazane SA, Choi SH, Yun HY, Kim MS, Rodgers DT, Pugh HM, Singer O, Sun SB, Fonslow BR, Kochenderfer JN, Wright TM, Schultz PG, Young TS, Kim CH, Cao Y. Versatile strategy for controlling the specificity and activity of engineered T cells. Proc Natl Acad Sci U S A. 2016;113(4):E450-8.

42. Cho JH, Collins JJ, Wong WW. Universal chimeric antigen receptors for multiplexed and logical control of T cell responses. Cell. 2018;173(6): $1426-38$.

43. Torikai H, Reik A, Liu PQ, Zhou Y, Zhang L, Maiti S, Huls H, Miller JC, Kebriaei P, Rabinovich B, Lee DA, Champlin RE, Bonini C, Naldini L, Rebar EJ, Gregory PD, Holmes MC, Cooper LJ. A foundation for universal T-cell based immunotherapy: T cells engineered to express a CD19-specific chimericantigen-receptor and eliminate expression of endogenous TCR. Blood. 2012; 119(24):5697-705.

44. Torikai H, Reik A, Soldner F, Warren EH, Yuen C, Zhou Y, Crossland DL, Huls H, Littman N, Zhang Z, Tykodi SS, Kebriaei P, Lee DA, Miller JC, Rebar EJ, Holmes MC, Jaenisch R, Champlin RE, Gregory PD, Cooper LJ. Toward eliminating HLA class I expression to generate universal cells from allogeneic donors. Blood. 2013;122(8):1341-9.

45. Poirot L, Philip B, Schiffer-Mannioui C, Le Clerre D, Chion-Sotinel I, Derniame S, Potrel P, Bas C, Lemaire L, Galetto R, Lebuhotel C, Eyquem J, Cheung GW, Duclert A, Gouble A, Arnould S, Peggs K, Pule M, Scharenberg AM, Smith J. Multiplex genome-edited T-cell manufacturing platform for "off-the-shelf" adoptive T-cell immunotherapies. Cancer Res. 2015;75(18):3853-64.

46. Georgiadis C, Preece R, Nickolay L, Etuk A, Petrova A, Ladon D, Danyi A, Humphryes-Kirilov N, Ajetunmobi A, Kim D, Kim JS, Qasim W. Long terminal repeat CRISPR-CAR-coupled "universal" T cells mediate potent anti-leukemic effects. Mol Ther. 2018;26(5):1215-27.

47. Knott GJ, Doudna JA. CRISPR-Cas guides the future of genetic engineering. Science. 2018;361(6405):866-9.

48. Doyon Y, Vo TD, Mendel MC, Greenberg SG, Wang J, Xia DF, Miller JC, Urnov FD, Gregory PD, Holmes MC. Enhancing zinc-finger-nuclease activity with improved obligate heterodimeric architectures. Nat Methods. 2011;8(1):74-9.

49. Urnov FD, Rebar EJ, Holmes MC, Zhang HS, Gregory PD. Genome editing with engineered zinc finger nucleases. Nat Rev Genet. 2010;11(9):636-46.

50. Kim S, Kim JS. Targeted genome engineering via zinc finger nucleases. Plant Biotechnol Rep. 2011;5(1):9-17.

51. Kim S, Lee MJ, Kim H, Kang M, Kim JS. Preassembled zinc-finger arrays for rapid construction of ZFNs. Nat Methods. 2011;8(1):7.

52. Boch J, Scholze H, Schornack S, Landgraf A, Hahn S, Kay S, Lahaye T, Nickstadt A, Bonas U. Breaking the code of DNA binding specificity of TALtype III effectors. Science. 2009;326(5959):1509-12.

53. Moscou MJ, Bogdanove AJ. A simple cipher governs DNA recognition by TAL effectors. Science. 2009;326(5959):1501.

54. Morbitzer R, Romer P, Boch J, Lahaye T. Regulation of selected genome loci using de novo-engineered transcription activator-like effector (TALE)-type transcription factors. Proc Natl Acad Sci U S A. 2010;107(50):21617-22.

55. Scholze H, Boch J. TAL effector-DNA specificity. Virulence. 2010;1(5):428-32.

56. Hockemeyer D, Wang H, Kiani S, Lai CS, Gao Q, Cassady JP, Cost GJ, Zhang L, Santiago Y, Miller JC, Zeitler B, Cherone JM, Meng X, Hinkley SJ, Rebar EJ, Gregory PD, Urnov FD, Jaenisch R. Genetic engineering of human pluripotent cells using TALE nucleases. Nat Biotechnol. 2011;29(8):731-4.

57. Miller JC, Tan S, Qiao G, Barlow KA, Wang J, Xia DF, Meng X, Paschon DE, Leung E, Hinkley SJ, Dulay GP, Hua KL, Ankoudinova I, Cost GJ, Urnov FD, 
Zhang HS, Holmes MC, Zhang L, Gregory PD, Rebar EJ. A TALE nuclease architecture for efficient genome editing. Nat Biotechnol. 2011;29(2):143-8,

58. Jinek M, Chylinski K, Fonfara I, Hauer M, Doudna JA, Charpentier E. A programmable dual-RNA-guided DNA endonuclease in adaptive bacterial immunity. Science. 2012;337(6096):816-21.

59. Dunbar CE, High KA, Joung JK, Kohn DB, Ozawa K, Sadelain M. Gene therapy comes of age. Science. 2018;359(6372). https://doi.org/10.1126/ science.aan 4672.

60. Tsai SQ, Joung JK. Defining and improving the genome-wide specificities of CRISPR-Cas9 nucleases. Nat Rev Genet. 2016;17:300.

61. Mollanoori H, Shahraki H, Rahmati Y, Teimourian S. CRISPR/Cas9 and CAR-T cell, collaboration of two revolutionary technologies in cancer immunotherapy, an instruction for successful cancer treatment. Hum Immunol. 2018;79. https://doi.org/10.1016/j.humimm.2018.1009.1007.

62. Ren J, Zhao Y. Advancing chimeric antigen receptor T cell therapy with CRISPR/Cas9. Protein Cell. 2017;8(9):634-43.

63. Esvelt KM, Mali P, Braff JL, Moosburner M, Yaung SJ, Church GM. Orthogonal Cas9 proteins for RNA-guided gene regulation and editing. Nat Methods. 2013;10(11):1116-21.

64. Mali P, Aach J, Stranges PB, Esvelt KM, Moosburner M, Kosuri S, Yang L, Church GM. CAS9 transcriptional activators for target specificity screening and paired nickases for cooperative genome engineering. Nat Biotechnol. 2013;31(9):833-8.

65. Mali P, Esvelt KM, Church GM. Cas9 as a versatile tool for engineering biology. Nat Methods. 2013;10(10):957-63.

66. Mali P, Yang L, Esvelt KM, Aach J, Guell M, DiCarlo JE, Norville JE, Church GM. RNA-guided human genome engineering via Cas9. Science. 2013; 339(6121):823-6.

67. Cong L, Ran FA, Cox D, Lin S, Barretto R, Habib N, Hsu PD, Wu X, Jiang W, Marraffini LA, Zhang F. Multiplex genome engineering using CRISPR/Cas systems. Science. 2013;339(6121):819-23.

68. Ren J, Zhang $X$, Liu X, Fang C, Jiang S, June $C H$, Zhao Y. A versatile system for rapid multiplex genome-edited CAR T cell generation. Oncotarget. 2017; 8(10):17002-11.

69. Liu X, Zhang Y, Cheng C, Cheng AW, Zhang X, Li N, Xia C, Wei X, Liu X, Wang H. CRISPR-Cas9-mediated multiplex gene editing in CAR-T cells. Cell Res. 2017;27(1):154-7.

70. Zhang Y, Zhang X, Cheng C, Mu W, Liu X, Li N, Wei X, Liu X, Xia C, Wang H. CRISPR-Cas9 mediated LAG-3 disruption in CAR-T cells. Front Med. 2017; 11(4):554-62.

71. Clarke RL, Svd S, Lee T, Mansilla-Soto J, C-w C, Sasaki J, Husain M, Peralta E, Hardy I, Ortiz E, Riviere I, Sadelain M, Valamehr B. Abstract LB-108: generation of off-the-shelf TCR-less CAR-targeted cytotoxic $T$ cells from renewable pluripotent cells for cancer immunotherapy. Cancer Res. 2018; 78(13 Supplement):LB-108

72. Qasim W, Zhan H, Samarasinghe S, Adams S, Amrolia P, Stafford S, Butler K, Rivat C, Wright G, Somana K, Ghorashian S, Pinner D, Ahsan G, Gilmour K, Lucchini G, Inglott S, Mifsud W, Chiesa R, Peggs KS, Chan L, Farzeneh F, Thrasher AJ, Vora A, Pule M, Veys P. Molecular remission of infant B-ALL after infusion of universal TALEN gene-edited CAR T cells. Sci Transl Med. 2017;9(374). https://doi.org/10.1126/scitransImed.aaj2013.

73. Fraietta JA, Nobles CL, Sammons MA, Lundh S, Carty SA, Reich TJ, Cogdill AP, Morrissette JJD, DeNizio JE, Reddy S, Hwang Y, Gohil M, Kulikovskaya I, Nazimuddin F, Gupta M, Chen F, Everett JK, Alexander KA, Lin-Shiao E, Gee MH, Liu X, Young RM, Ambrose D, Wang Y, Xu J, Jordan MS, Marcucci KT, Levine BL, Garcia KC, Zhao Y, et al. Disruption of TET2 promotes the therapeutic efficacy of CD19-targeted T cells. Nature. 2018;558(7709):307-12.

74. Ruella M, XU J, Barrett DM, Fraietta JA, Reich TJ, Ambrose DE, Klichinsky M, Shestova O, Patel PR, Kulikovskaya I, Nazimuddin F, Bhoj VG, Orlando EJ, Fry TJ, Bitter H, Maude SL, Levine BL, Nobles CL, Bushman FD, Young RM, Scholler J, Gill SI, June CH, Grupp SA, Lacey SF, Melenhorst JJ. Induction of resistance to chimeric antigen receptor $\mathrm{T}$ cell therapy by transduction of a single leukemic B cell. Nat Med. 2018;24(10):1499-503.

Ready to submit your research? Choose BMC and benefit from:

- fast, convenient online submission

- thorough peer review by experienced researchers in your field

- rapid publication on acceptance

- support for research data, including large and complex data types

- gold Open Access which fosters wider collaboration and increased citations

- maximum visibility for your research: over $100 \mathrm{M}$ website views per year

At BMC, research is always in progress.

Learn more biomedcentral.com/submissions 